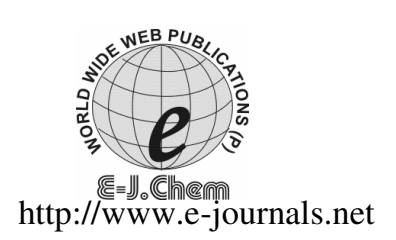

ISSN: 0973-4945; CODEN ECJHAO

E-Journal of Chemistry 2011, 8(1), 217-225

\title{
Determination of Traces of Pd(II) in Spiked Samples by Using 3,4-Dihydroxybenzaldehydeisonicotinol- hydrazone as a Chelating Agent with UV Visible Spectrophotometer
}

\author{
S. LAKSHMI NARAYANA ${ }^{\S}$, C. RAMACHANDRAIAH ${ }^{\#}$, \\ A.VARADA REDDY, DONGYEUN LEE ${ }^{\S}$ and JAESOOL SHIM ${ }^{\S *}$ \\ ${ }^{\S}$ School of Mechanical Engineering, Yeungnam University \\ Gyeongsan-si, Korea-712 749 \\ "Department of Chemistry \\ Sri Kalahastheeswara Institute of Technology, Sri Kalahasthi, India \\ Analytical Division, Department of Chemistry \\ Sri Venkateswara University, Tirupati-517 502, India \\ jshim@ynu.ac.kr
}

Received 6 May 2010; Accepted 18 July 2010

\begin{abstract}
A simple, rapid, sensitive and inexpensive method has been developed for the determination of trace amounts of palladium(II) using 3,4-dihydroxybenzaldehydeisonicotinoylhydrazone (3,4-DHBINH). The metal ion gives a yellow colored complex with 3,4-DHBINH in acetate buffer of $\mathrm{pH} 3.0$ with 1:1 (metal: ligand) composition. The complex shows maximum absorption at $380 \mathrm{~nm}$. Beer's law is obeyed in the range $0.5-20.0 \mathrm{ppm}$ of Pd(II). The molar absorptivity, Sandell's sensitivity and detection limit were found to be $0.53 \times 10^{4} \mathrm{~L} \mathrm{~mol}^{-1} \mathrm{~cm}^{-1}$, $0.02 \mu \mathrm{g} \mathrm{cm}^{-2}$ and $0.0948 \mu \mathrm{g} \mathrm{mL}^{-1}$, respectively. The correlation coefficient and regression coefficient of the $\mathrm{Pd}(\mathrm{II})-3,4-\mathrm{DHBINH}$ complex were 1.08 and 0.04 respectively. Major cations and anions did not show any interference. Antimicrobial activity of the Pd(II)-3,4-DHBINH has been studied. The developed method has been successfully applied to the analysis of $\operatorname{Pd}(\mathrm{II})$ in spiked samples. Comparing the results with those obtained using an atomic absorption spectrophotometer tested the validity of the method
\end{abstract}

Keywords: Trace, Palladium, Spectrophotometer, Chelating agent

\section{Introduction}

Palladium and its alloys have a wide range of applications both in the chemical industry and in instrument making ${ }^{1}$. Environmental contamination by the platinum group element (PGEs), 
mainly related to automotive catalytic converters, is exponentially increasing and reliable and accurate quantification is a mandatory task. The wide use of palladium not only in automotive catalytic converters but also as a drug and in food production has led to a more uncontrolled release of those metals in the environment ${ }^{2}$. Palladium is one of the precious metals. Owing to its corrosion resistant nature and alloying ability, palladium is an important element in metallurgy. Its alloys are used in dental and medicinal devices and in jewelry manufacture. Palladium-cobalt alloys show catalytic activity in the hydrogenation of nitrile function ${ }^{3}$. Moreover, palladium is used in automobile catalysts together with $\mathrm{Pt}$ and $\mathrm{Rh}^{4}$.

For the determination of palladium at micro amount levels, there are several frequently adopted methods using analytical techniques, such as AAS, ICP-AES, ICP-MS, X-ray fluorescence spectroscopy, spectrophotometry, spectrofluorometry and such other techniques. Among these, spectrophotometric methods are preferred because they are cheaper and easy to handle. Many physiologically active hydrazones find application in the treatment of diseases like tuberculosis, leprosy and mental disorders. Hydrazones also act as herbicides, insecticides, nematocides, rodenticides and plant growth regulators.

Isonicotinoylhydrazide (INH) is an important antitubercular agent and has potential sites for formation of complexes with metal ions. The potential use of hydrazone derivatives in analytical chemistry, for the spectrophotometric determination of ions has been reviewed by Singh $e t . a l^{5}$. It appeared through the scan of the available literature that little attention has been paid to the use of isonicotinoylhydrazones of substituted carbonyl compounds for spectrophotometric determination of palladium. Since, focus of interests in the study of the analytical usefulness of 3, 4-dihydroxybenzaldehydeisonicotinoylhydrazone, for the spectrophotometric determination of such important metal palladium(II), a new method for the spectrophotometric determination of $\mathrm{Pd}(\mathrm{II})$ using 3,4-dihydroxybenzaldehydeisonicotinoylhydrazone (3,4-DHBINH) is proposed in this work. This method is rapid, sensitive, inexpensive and superior to most of the reported methods ${ }^{6-15}$ in simplicity.

\section{Experimental}

\section{Apparatus}

A recording spectrophotometer (model Shimadzu 2450) was employed in photometric studies. A Perkin - Elmer 2380 atomic - absorption spectrophotometer was employed for the comparison of the results of the samples. A digital pH meter (model Elico LI - 129) was used for measuring the $\mathrm{pH}$ of the solutions.

\section{Preparation of a stock solution of palladium(II)}

$1.664 \mathrm{~g}$ of palladium(II) chloride was dissolved in a minimum amount of $2 \mathrm{M}$ hydrochloric acid solution in a one liter volumetric flask, and was finally made up to the mark with $2 \mathrm{M}$ hydrochloric acid solution. This stock solution was standardized gravimetrically using dithizone ${ }^{16}$.

\section{Preparation of 3, 4- dihydroxybenzaldehydeisonicotinoylhydrazone}

Equimolar quantities of 3,4-dihydroxybenzaldehyde (3,4-DHB) dissolved in alcohol and aqueous isonicotinoylhydrazide (INH) were taken in a $500 \mathrm{~mL}$ round bottom flask and refluxed for 2-3 h. The contents were cooled and then filtered. The product (Scheme 1) obtained was washed with aqueous methanol and finally recrystallized from rectified spirit. The purity of the reagent was checked by TLC and melting point analysis (m.p. $218-219^{\circ} \mathrm{C}$ ).

It is evident from I.R. spectrum of the ligand that, $\mathrm{C}=\mathrm{N}$ group is present in the compound because the peak appears at $1600 \mathrm{~cm}^{-1} . \mathrm{C}=\mathrm{O}$ (Stretching) amide peak appears at $1656.9 \mathrm{~cm}^{-1} . \mathrm{OH}$ group peak appears at $3484.6 \mathrm{~cm}^{-1}$, -NH peak appears at $3245 \mathrm{~cm}^{-1}$. From the above data it is 
confirmed the formation of 3,4-dihydroxybenzaldehydeisonicotinoylhdrazone. A $0.1 \mathrm{M}$ stock solution was prepared by dissolving $2.57 \mathrm{~g}$ of 3,4-DHBINH in $40 \%$ aqueous dimethyl formamide.<smiles></smiles>

3, 4-DHB

INH

3, 4-DHBINH

Scheme 1. Formation of 3, 4-DHBINH

\section{Buffer solutions}

Solutions of 1.0 M sodium acetate and 1.0 M acetic acid were prepared in double distilled water. Suitable portions of these solutions were mixed to get the desired $\mathrm{pH}$ of the solution.

Procedure for determination of Pd(II)

$1.0 \mathrm{~mL}$ of $\mathrm{Pd}(\mathrm{II})$ solution was placed in a test tube; the $\mathrm{pH}$ was adjusted to 3.0 by the addition of $\mathrm{CH}_{3} \mathrm{COOH}+\mathrm{CH}_{3} \mathrm{COONa}$ buffer. $1.0 \mathrm{~mL}$ of $3,4-\mathrm{DHBINH}$ solution was added. The contents in the test tube were diluted to $10.0 \mathrm{~mL}$. The absorbance was measured at $380 \mathrm{~nm}$ against a reagent blank.

\section{Results and Discussion}

Absorption spectra

The absorption spectra in the 300-600 nm range for 3,4- DHBINH and Pd(II)- 3,4-DHBINH complex are shown in Figure 1. The formation of the $380 \mathrm{~nm}$ band in figure 1 must be connected with chelate formation between Pd(II) and 3,4-DHBINH .

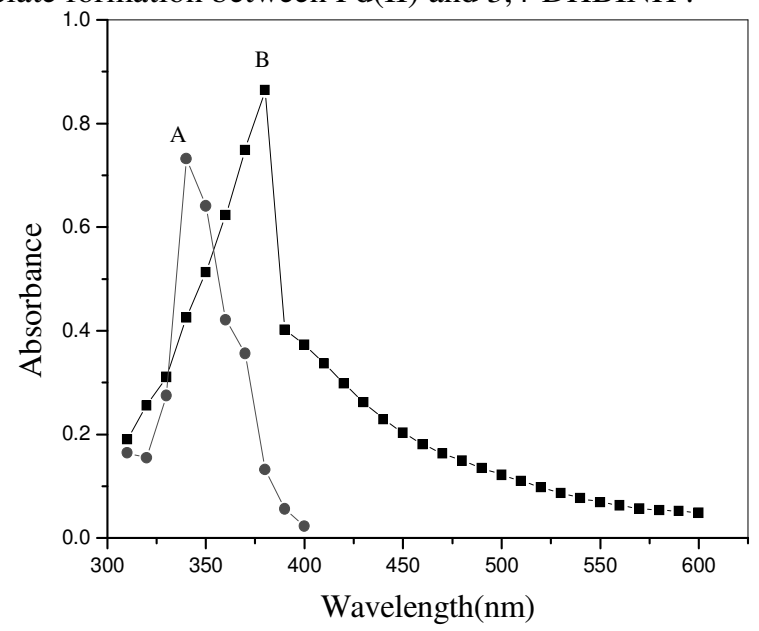

Figure 1. Absorption spectra of (a) 3,4-DHBINH; $\quad$ (b) Pd(II)-3,4-DHBINH complex; Pd(II): $1 \mathrm{~mL}$ of $1.0 \times 10^{-4} \mathrm{M} ; 3,4-\mathrm{DHBINH}: 1.0 \mathrm{~mL}$ of $1.0 \times 10^{-3} \mathrm{M} ; \mathrm{pH}: 3$.

\section{Effect of $p H$}

The effect of $\mathrm{pH}$ on the absorption of the complex was studied at $380 \mathrm{~nm}$ with solutions containing $1.0 \times 10^{-4} \mathrm{M}$ Pd(II) solution and $1.0 \times 10^{-3} \mathrm{M} 3,4-\mathrm{DHBINH}$. The spectrum of the Pd(II)3,4-DHBINH solution was strongly dependent on the $\mathrm{pH}$ of the solution. Our experiments showed that the complex has maximum absorbance at $\mathrm{pH}$ 3.0. The optimum working $\mathrm{pH}$ was found to be $\mathrm{pH}$ 3.0. The plot between $\mathrm{pH}$ and absorbance of complex is shown in Figure 2. 


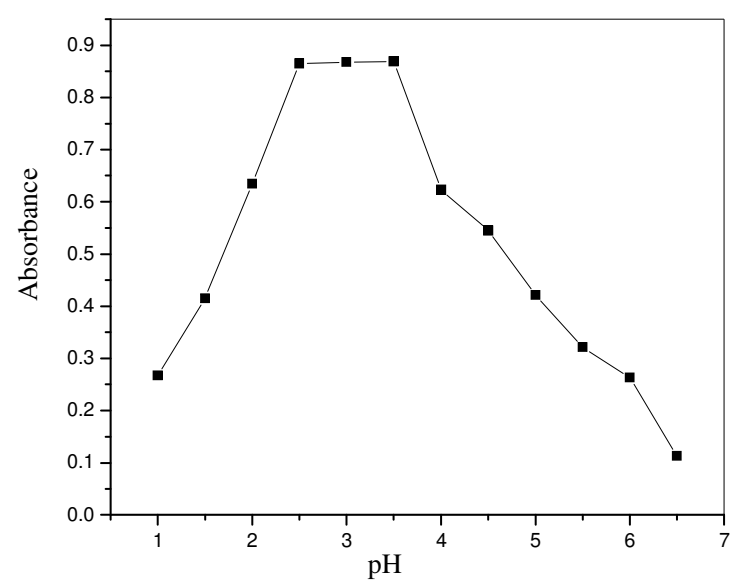

Figure 2. Effect of $\mathrm{pH}$ on $\mathrm{Pd}(\mathrm{II})$ - 3,4-DHBINH complex; $\mathrm{Pd}(\mathrm{II}): 1 \mathrm{~mL}$ of $1.0 \times 10^{-4} \mathrm{M}$; 3,4-DHBINH: $1.0 \mathrm{~mL}$ of $1.0 \times 10^{-3} \mathrm{M} ; \lambda_{\max }: 380 \mathrm{~nm}$.

\section{Effect of reagent concentration}

The influence of excess of reagent concentration on the absorbance of the complex was studied. The absorbance of $1.0 \times 10^{-4} \mathrm{M} \mathrm{Pd}(\mathrm{II})$ solution after the addition of varying concentrations of 3, 4-DHBINH ranging from $1.0 \times 10^{-4} \mathrm{M}$ to $20 \times 10^{-4} \mathrm{M}$ at $\mathrm{pH} 3.0$ was measured at $380 \mathrm{~nm}$; the reaction of $\mathrm{Pd}(\mathrm{II})$ with 3,4-DHBINH solution increased in sensitivity with increasing solution concentration. It is almost consistent after ten fold excess of the reagent concentration with respect to metal concentration. Hence ten fold molar excess of reagent was considered for further studies.

\section{Applicability of Beer's law}

Known aliquots of $10.0 \mathrm{~mL}$ solutions, each containing constant volumes of $4.0 \mathrm{~mL}$ of buffer $(\mathrm{pH}=3.0), 1.0 \mathrm{~mL}$ of $10.0 \times 10^{-4} \mathrm{~mol} \mathrm{~L}^{-1}$ reagent and $1.0 \mathrm{~mL}$ of $\mathrm{Pd}(\mathrm{II})$ containing $0.5-28.0 \mu \mathrm{g} \mathrm{mL}^{-1}$ were prepared. The absorbance of these solutions was measured at $380 \mathrm{~nm}$. A graph plotted between the amount of $\operatorname{Pd}(\mathrm{II})$ and its absorbance is shown in Figure 3. It can be observed from the graph that a linear plot passing through the origin obeys Beer's law in the range $0.5-20.0 \mu \mathrm{g} \mathrm{mL}^{-1}$ of $\mathrm{Pd}(\mathrm{II})$.

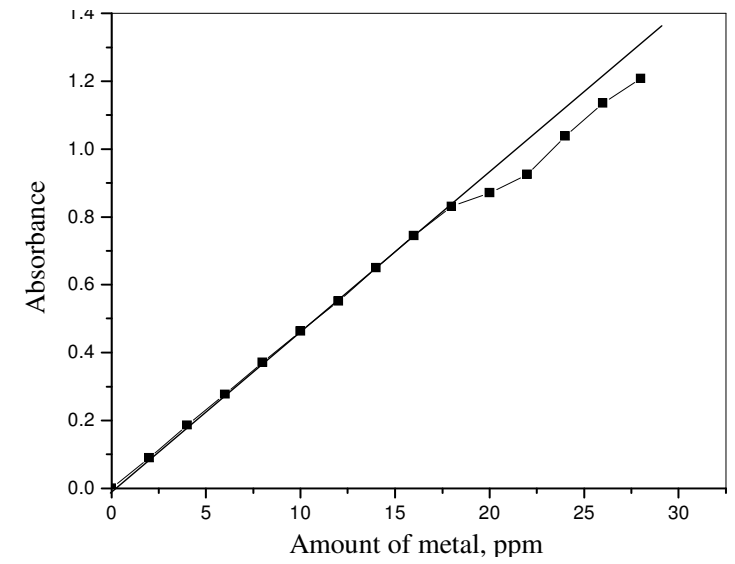

Figure 3. Applicability of Beer's law to Pd(II)- 3,4-DHBINH complex; 3,4 -DHBINH: $1.0 \mathrm{~mL}$ of $1.0 \times 10^{-3} \mathrm{M} ; \mathrm{pH}: 3.0 ; \lambda_{\max }: 380 \mathrm{~nm}$. 


\section{Molar absorptivity, Sandell's sensitivity and correlation co-efficient}

The molar absorptivity of the complex was calculated to be $0.533 \times 10^{4} \mathrm{~L} \mathrm{~mol}^{-1} \mathrm{~cm}^{-1}$ and Sandell's sensitivity of the complex obtained from Beer's law data was $0.02 \mu \mathrm{g} \mathrm{cm}^{-2}$ at $380 \mathrm{~nm}$ The correlation coefficient of the Pd(II)-3,4-DHBINH complex was 1.00, which indicated an excellent linearity between the two variables.

Ringbom plot for the Pd-3,4-DHBINH complex

A Ringbom plot is an established standard adopted to know the optimum range of concentration for a system that obeys Beer's law. A Ringbom plot was drawn between $\log \mathrm{C}$ of $\mathrm{Pd}(\mathrm{II})$ and (1-T), where $\mathrm{T}$ is transmittance. The plot has a sigmoid shape with a linear segment at intermediate absorbance values (0.371-0.650) and concentration values (8.0$\left.14.0 \mu \mathrm{g} \mathrm{mL}^{-1}\right)$. The slope of the Ringbom plot from Figure 4, is 0.534 . Hence the ratio between the relative error in concentration and photometric error is 4.3127 for a one percent photometric error, $\Delta \mathrm{P}=0.01$. Hence the relative error in the concentration is 0.0431 .

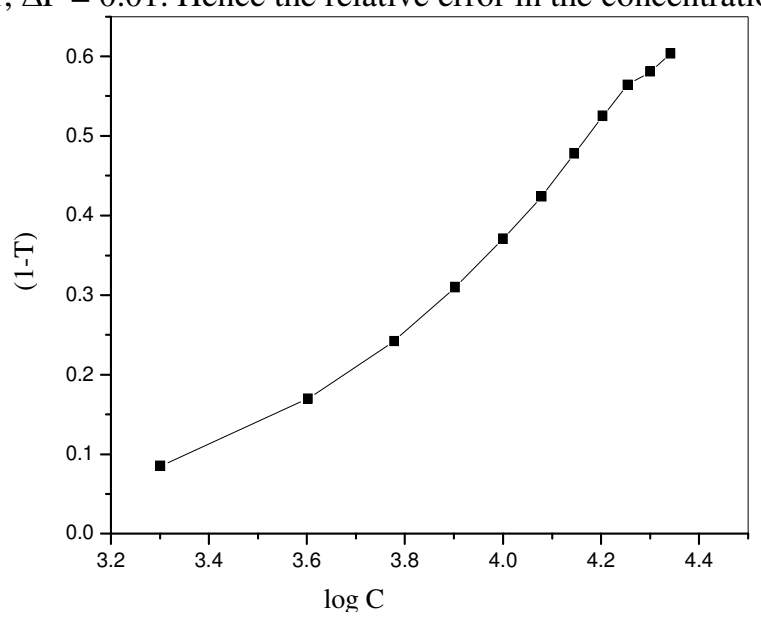

Figure 4. Ringbom's plot of $\mathrm{Pd}(\mathrm{II})$ - 3,4-DHBINH complex ; $\mathrm{Pd}(\mathrm{II}): 2000-24000 \mu \mathrm{g} \mathrm{L}^{-1}$; 3,4 -DHBINH: $1.0 \mathrm{~mL}$ of $1.0 \times 10^{-3} \mathrm{M}$; $\mathrm{pH}: 3.0 ; \lambda_{\max }: 380 \mathrm{~nm}$.

\section{Precision and accuracy of the method and detection limit of the method}

To assess the precision of the method, determinations were carried out with different concentrations of $\mathrm{Pd}(\mathrm{II})$ under optimum conditions. The standard deviation was found to be not more than 0.0015 and the relative standard deviation was less than $0.427 \%$. It is evident from these results that the method is precise, besides being accurate. The detection limit was determined as the amount of $\mathrm{Pd}(\mathrm{II})$ corresponding to thrice the standard deviation blank value. A value of $0.095 \mu \mathrm{g} \mathrm{mL}^{-1}$ was obtained.

\section{Composition of the Pd(II)- 3,4-DHBINH complex}

Job's method of continuous variation, the molar-ratio method and Asmus's method were employed to elucidate the composition of the complex. Equimolar solutions of $\mathrm{Pd}(\mathrm{II})$ and 3,4 -DHBINH $\left(1.0 \times 10^{-4} \mathrm{~mol} \mathrm{~L}^{-1}\right)$ were used to determine the metal to ligand ratio by Job's method of continuous variation. The absorbance values were recorded at $380 \mathrm{~nm}$ against the reagent blank. A plot was drawn between the absorbance and $V_{M} / V_{M}+V_{L}$, where $V_{M}$ and $V_{L}$ are the volumes of the reagent and metal, respectively. The obtained curve shown in Figure 5 is indicative of 1:1 stoichiometry in the complex. This was further confirmed by molar-ratio 
method (Figure 6). Finally the composition of the complex was verified by Asmus's method. Based on these experiments the probable structure of the complex is deduced as follows.<smiles></smiles>

Pd(II)-3,4-DHBINH Complex

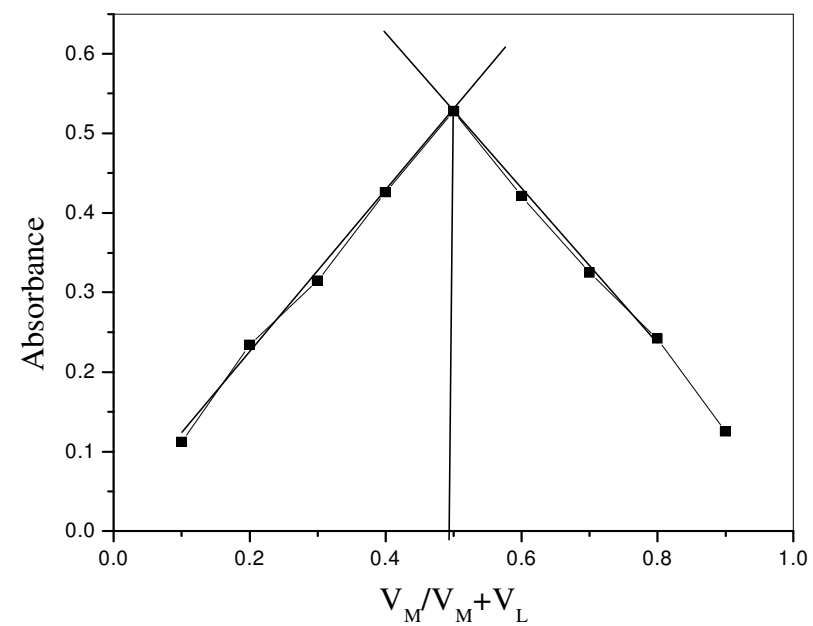

Figure 5. Job's method of continuous variation of $\mathrm{Pd}(\mathrm{II})$ - 3,4-DHBINH complex; Pd(II) and 3,4-DHBINH: $1.0 \mathrm{~mL}$ of $1.0 \times 10^{-4} \mathrm{M}$; pH:3.0; $\lambda_{\max }: 380 \mathrm{~nm}$.

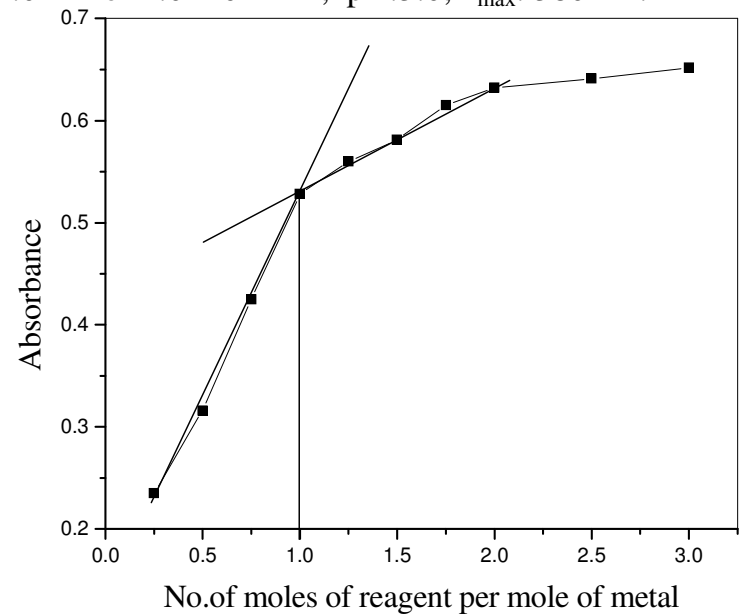

Figure 6. Mole- ratio method of Pd(II) - 3,4-DHBINH complex; Pd(II) and 3,4- DHBINH: $1.0 \mathrm{~mL}$ of $1.0 \times 10^{-4} \mathrm{M} ; \mathrm{pH}: 3.0 ; \lambda_{\max }: 380 \mathrm{~nm}$.

Effect of foreign ions

The effect of foreign ions on complexation was studied by taking $1.0 \mathrm{~mL}$ of $\mathrm{Pd}(\mathrm{II})$ solution, $1.0 \mathrm{~mL}$ of required concentration of the foreign ion solution, $4.0 \mathrm{~mL}$ of buffer $(\mathrm{pH}=3.0)$ and $2.0 \mathrm{~mL}$ of 3,4- DHBINH solution in a $10.0 \mathrm{~mL}$ standard flask. The total volume of the 
solution was brought to $10.0 \mathrm{~mL}$ with double distilled water. The experiment was repeated by changing the concentration of the diverse ion. The absorbances were measured at $380 \mathrm{~nm}$. A change of \pm 0.02 was taken as the tolerance limit for interference. The interference of various ions in the determination of $\mathrm{Pd}(\mathrm{II})$ is reported in Table 1.

\section{Applications}

The developed extractive spectrophotometric method for palladium(II) was successfully applied for its determination in water samples and synthetic mixtures.

\section{Analysis of palladium(II) in water samples}

Various water samples were prepared ${ }^{17}$ with different compositions of palladium(II) and analyzed by employing the proposed developed procedure. The results are in perfect agreement with those obtained by direct atomic absorption spectrometry. The results are given in Table 2 .

Table 1. Tolerance limit of diverse ions in the determination of $\operatorname{Pd}(\mathrm{II})$

\begin{tabular}{cccc}
\hline Diverse ion & $\begin{array}{c}\text { Tolerance limit } \\
\mu \mathrm{g} \cdot \mathrm{mL}^{-1}\end{array}$ & Diverse ion & $\begin{array}{c}\text { Tolerance limit } \\
\mu \mathrm{g} \cdot \mathrm{mL}^{-1}\end{array}$ \\
\hline $\begin{array}{c}\text { Ascorbic acid, } \\
\text { Thiocyanate }\end{array}$ & 15000 & $\mathrm{Mg}(\mathrm{II}), \mathrm{Ca}(\mathrm{II})$ & 6000 \\
Sulphate & 10000 & $\mathrm{Ba}(\mathrm{II}), \mathrm{Mn}(\mathrm{II}) \mathrm{Fe}(\mathrm{III})$ & 4500 \\
Thiourea & 8500 & $\mathrm{Al}(\mathrm{III}), \mathrm{NI}(\mathrm{II}), \mathrm{Ag}(\mathrm{I})$ & 3500 \\
Iodide & 5500 & $\mathrm{Zn}(\mathrm{II})$ & 2500 \\
Tartrate & 3000 & $\mathrm{Cu}(\mathrm{II})$ & 500 \\
Oxalate & 2750 & & \\
Phosphate & 2500 & & \\
\hline
\end{tabular}

Tabl e 2. Determination of palladium(II) in water samples

\begin{tabular}{ccccccc}
\hline S.No. & \multirow{2}{*}{$\begin{array}{c}\text { Palladium(II) } \\
\text { added } \mu \mathrm{g} \mathrm{mL} \mathrm{mL}^{-1}\end{array}$} & \multicolumn{2}{c}{ Palladium(II) found } & \multirow{2}{*}{ S.D. } & \multirow{2}{*}{ R.S.D. } \\
\hline Sample 1 & 0 & 0 & Present method & & \\
Sample 2 & 5 & 4.95 & 4.89 & 0.0357 & 0.737 \\
Sample 3 & 10 & 9.98 & 9.92 & 0.0234 & 0.236 \\
Sample 4 & 15 & 14.96 & 14.85 & 0.0245 & 0.165 \\
Sample 5 & 20 & 19.97 & 19.70 & 0.0 .23 & 0.117 \\
\hline
\end{tabular}

\section{Analysis of palladium(II) in synthetic mixtures}

Various synthetic mixtures were prepared ${ }^{17}$ and analyzed by employing the proposed developed procedure. The results are in perfect agreement with those obtained by direct atomic absorption spectrometer. The results are given in Table 3.

Table 3. Determination of Palladium in synthetic mixtures

\begin{tabular}{|c|c|c|c|c|c|}
\hline $\begin{array}{l}\text { Synthetic mixture composition } \\
\mu \mathrm{g} . \mathrm{mL}^{-1}\end{array}$ & $\begin{array}{l}\text { Pd(II) added } \\
\mu g \mathrm{~mL}^{-1}\end{array}$ & $\begin{array}{l}\text { Palla } \\
\text { AAS }\end{array}$ & $\begin{array}{l}\text { dium }(\mathrm{II})^{\mathrm{a}} \text { found } \\
\text { Present method }\end{array}$ & S.D. & $\begin{array}{l}\text { R.S.D } \\
\%\end{array}$ \\
\hline $\begin{array}{l}\begin{array}{l}4.0 \mathrm{Fe}(\mathrm{III})+4.0 \\
\mathrm{Cu}(\mathrm{II})^{*}\end{array}\end{array}$ & 10.00 & 9.98 & 9.85 & 0.0291 & 0.296 \\
\hline $\begin{array}{l}2.0 \mathrm{Al}(\mathrm{III})+3.0 \mathrm{Ni}(\mathrm{II})+3.0 \\
\operatorname{Ag}(\mathrm{I})\end{array}$ & 12.00 & 11.95 & 11.86 & 0.0283 & 0.239 \\
\hline $3.0 \mathrm{Co}(\mathrm{II})+3.0 \mathrm{Mn}(\mathrm{II})+2.0 \mathrm{Zn}(\mathrm{II})$ & 14.00 & 13.97 & 13.89 & 0.0223 & 0.160 \\
\hline
\end{tabular}




\section{Conclusion}

3,4-Dihydroxybenzldehydeisonicotinolhydrazone a new reagent is proved to be the best reagent for the determination of palladium(II) when compared to some other spectrophotometric methods reported earlier ${ }^{7-16}$ (Table 4). This method was successfully applied for the determination of palladium(II) in water samples and synthetic mixtures.

Table 4. Comparison of the present method with the other spectrophotometric methods for the determination of palladium(II)

\begin{tabular}{|c|c|c|c|c|c|c|c|}
\hline S.No & Reagent & $\mathrm{pH}$ & $\begin{array}{c}\lambda_{\max } \\
\mathrm{nm}\end{array}$ & $\begin{array}{l}\in \\
\mathrm{Lmol}_{\max } \times 10^{-1} \mathrm{~cm}^{-1}\end{array}$ & M:L & $\begin{array}{l}\text { Beer's } \\
\text { law range } \\
/ \mu \mathrm{g} . \mathrm{mL}^{-1}\end{array}$ & Ref \\
\hline 1 & $\begin{array}{l}\text { 5-Methyl-2,3-hexa- } \\
\text { nedione dioxime }\end{array}$ & $0.5-1.5$ & 379 & 0.389 & $1: 2$ & $50-9000$ & 7 \\
\hline 2 & $\begin{array}{l}\text { Glyoxalbis(4-phen- yl- } \\
\text { 3-thiosemicarba- zone) }\end{array}$ & 9.6 & 635 & 0.320 & $1: 1$ & N.R & 8 \\
\hline 3 & $\begin{array}{l}\text { Phenanthraquinine } \\
\text { monothiosemicarbazone }\end{array}$ & N.R & 540 & 0.420 & N.R & $1.3-6.7$ & 9 \\
\hline 4 & $\begin{array}{l}\text { 3-Phenoxybenzal- } \\
\text { doxime }\end{array}$ & 4.0 & 435 & 0.2434 & N.R & $0.4-4.0$ & 10 \\
\hline 5 & $\begin{array}{l}\text { Furfurylacroline } \\
\text { thiosemicarbozone }\end{array}$ & $2.0-10.0$ & 390 & 0.41 & N.R & N.R & 11 \\
\hline 6 & $\begin{array}{l}\text { Benzyloxybenzaldehyde- } \\
\text { thiosemicarbazone }\end{array}$ & 5.0 & 365 & 0.4 & $1: 1$ & $\begin{array}{l}5.0-60 \\
\mu \mathrm{g} / \mathrm{mL}\end{array}$ & 12 \\
\hline 7 & $\begin{array}{l}\text { 2-Arylthio-phenyol- } \\
\text { nitroaceto-phenone }\end{array}$ & $5-0$ & 430 & 0.1612 & NR & $2.5-2-0$ & 13 \\
\hline 8 & $\begin{array}{l}\text { 2-Mercapto - } 5 \text { anilino } \\
1,3,4 \text { - thiadiazole. }\end{array}$ & $\begin{array}{l}\text { Basic } \\
\text { medium }\end{array}$ & $\begin{array}{l}312 \\
260\end{array}$ & $\begin{array}{l}0.3209 \\
0.2329\end{array}$ & $1: 2$ & $0.33-10.66$ & 14 \\
\hline 9 & Chromocitromin B-H & $2-3$ & 470 & 0.1 & $1: 1$ & NR & 15 \\
\hline 10 & $\begin{array}{l}\text { 7-Iodo }-8-\text { hydroxy } \\
\text { quinoline }-5- \\
\text { Sulphonic acid }\end{array}$ & NR & 430 & 0.0958 & NR & $\begin{array}{l}2.5 \text {-wide } \\
\text { range }\end{array}$ & 16 \\
\hline 11 & $\begin{array}{l}\text { 3,4-Dihydroxybenzalde } \\
\text { hydeisonicotinoyl- } \\
\text { hydrazone }\end{array}$ & 3.0 & 380 & 0.533 & $1: 1$ & $0.5-20.0$ & $\begin{array}{l}\text { Present } \\
\text { method }\end{array}$ \\
\hline
\end{tabular}

\section{Acknowledgment}

One of the authors S. Lakshmi Narayana is greatly thankful to Council of Scientific and Industrial Research, New Delhi, India for awarding Senior Research Fellowship. This research was supported by Future-based Technology Development Program (Nano Fields) through the National Research Foundation of Korea (NRF) funded by the Ministry of Education, Science and Technology (2010-0019110)

\section{References}

1 Lokhande T N, Anuse M A and Chavan M B, Talanta, 1998, 46,163-169.

2 Dong X, Han Y, Hu Q, Chen H and Yang G, J Braz, Chem Soc., 2006, 17(1), 189-193.

3 Bagherian G, Chamjangali M A and Eskandari H, J Spectrochimica Acta Part A, 2007, 62(2), 378-384. 
4 Tunceli A. and Turker, A R, Anal Sci., 2000, 16, 81.

$5 \quad$ Singh R B, Jain P and Singh R P, Talanta, 1982, 29, 77-84.

6 Tandel P S, Jadhav B S and Malve P S, Indian J Chem., 2001, 40A, 1128-1129.

7 Asuero A, Jimenez A M and Herrador M A, Analyst, 1986, 111(7), 747-755.

8 Shravah K, Sinha P P and Sindhwani S K, Analyst, 1986, 111, 1339-1340.

9 Lokhande R S, Nemade H G, Chaudhory A B and Hundiwale D G, Asian J Chem., 2001, 13(2), 596-602.

10 Lokhande R S, Nemade H G, Choudhory A B and Handiwale D G, Asian J Chem., 2001, 13(2), 596.

11 Lakshmi Narayana S, Janardhan Reddy K, Adinarayana Reddy S, Rajesh Kumar J and Varada Reddy A, J Chinese Chem Soc., 2007, 54, 1233-1241.

12 Gajare P T, Gaikwad S H and Anuse M.A, J Chem, Environ., 2001, 5(3), 51.

13 Roman Liviu, Cvaciuneanu Rodica and Popper Ervin, Mikrochim Acta, 1968, 3, 660-663.

14 Roman L, Cvaciuneanu R and Popper E, Mikrochim Acta, 1968, 3, 660-663.

15 Singh Tej and Dey Arun. K, Talanta, 1971, 18(2), 225-228.

16 Marczenko Z, Spectrophotometric Determination of Elements, Ellis Horwood Ltd, England, 1976, 412-420.

17 Vogel A I, A text Book of Quantitative Inorganic Analysis, 3 ${ }^{\text {rd }}$ Ed., 1961, Longmann,Green,London. 


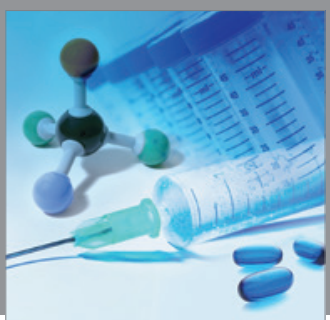

International Journal of

Medicinal Chemistry

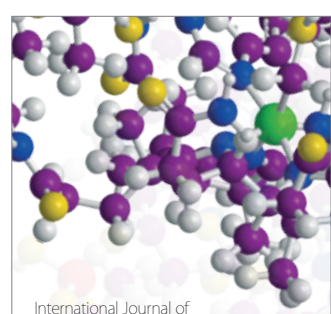

Carbohydrate Chemistry



The Scientific World Journal

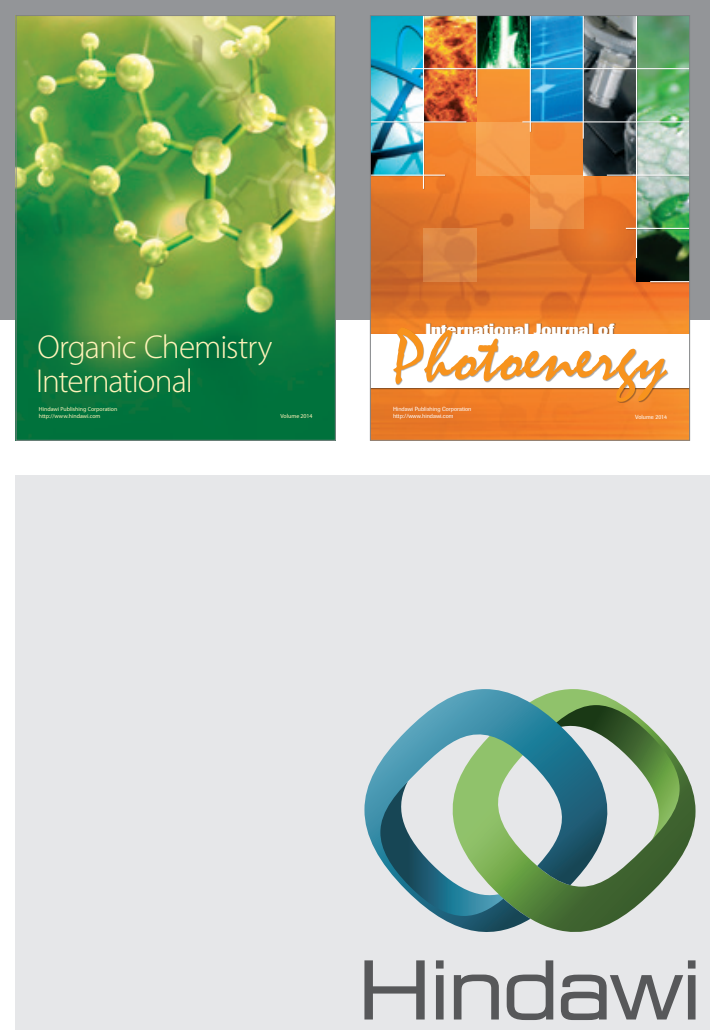

Submit your manuscripts at

http://www.hindawi.com
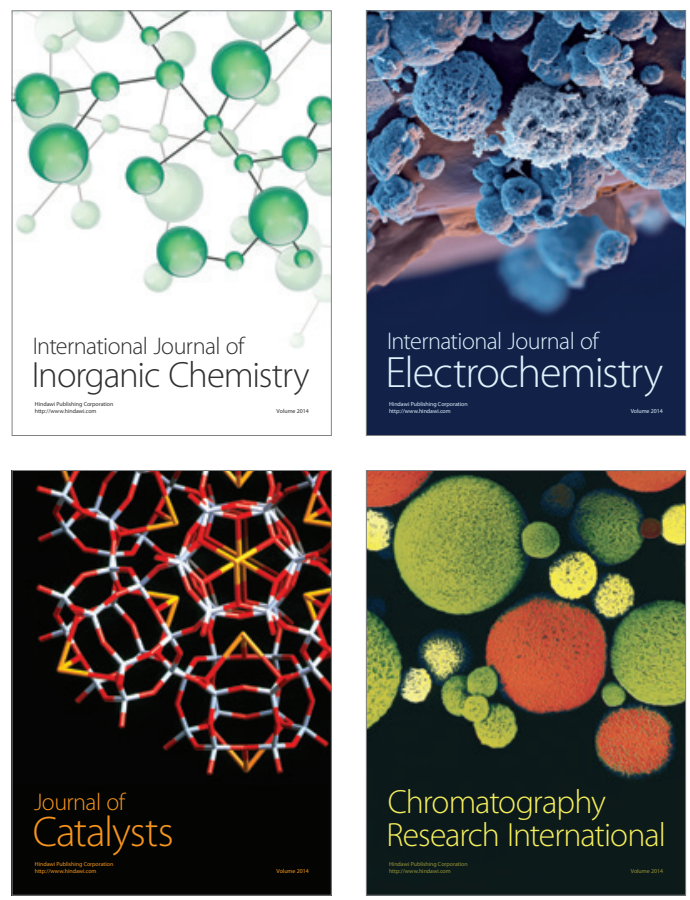
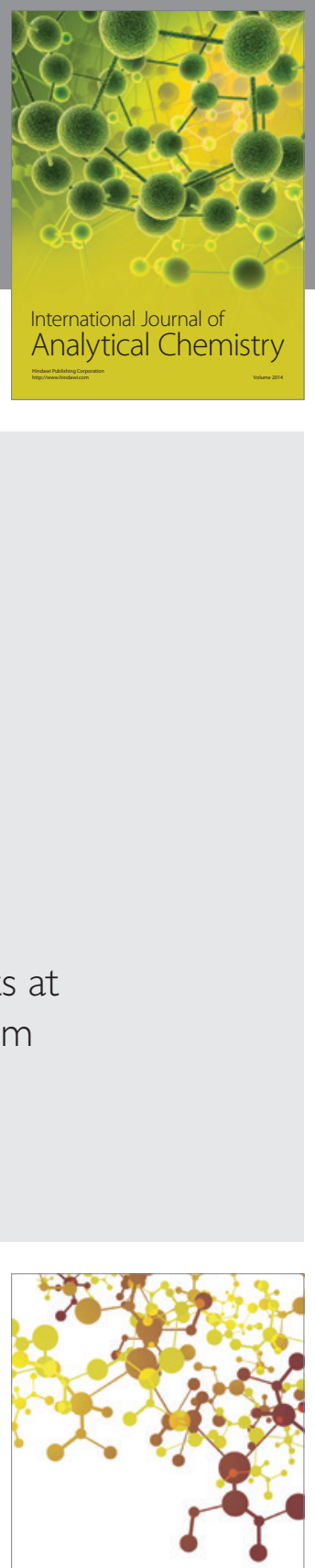

Journal of

Applied Chemistry
